MIDPI

sciforum
MOL2NET, International Conference Series on Multidisciplinary Sciences

CHEMBIOMOL-07: Chem. Biol. \& Med. Chem. Workshop, Bilbao-Rostock,

\title{
Protease production from Lysinibacillus fusiformis strain C250R: Statistical optimization and compatibility study for use in detergent formulations
}

\author{
Sondes Mechri ${ }^{a^{*}}$, Khelifa Bouacem ${ }^{b}$, Mouna Kriaa $^{a}$, Alif Chebbic, Sami Sayadic, \\ Mohamed Chamkha ${ }^{c}$, Amel Bouanane-Darenfed ${ }^{b}$ Hocine Hacene $^{b}$, Bassem Jaouadi $^{a}$
}

*E-mail addresses: sondes.mechri@yahoo.com \& bassem.jaouadi@cbs.rnrt.tn.

a Laboratory of Microbial Biotechnology, Enzymatic, and Biomolecules (LMBEB), Centre of Biotechnology of Sfax (CBS), University of Sfax, P.O. Box 1177, Sfax 3018, Tunisia

${ }^{b}$ Laboratory of Cellular and Molecular Biology (LCMB), Microbiology Team, Faculty of Biological Sciences, University of Sciences and Technology of Houari Boumediene (USTHB), P.O. Box 32, El Alia, Bab Ezzouar, 16111 Algiers, Algeria

${ }^{c}$ Laboratory of Environmental Bioprocesses (LEBP), LMI COSYS-Med, Centre of Biotechnology of Sfax (CBS), University of Sfax, Road of Sidi Mansour Km 6, P.O. Box 1177, Sfax 3018, Tunisia

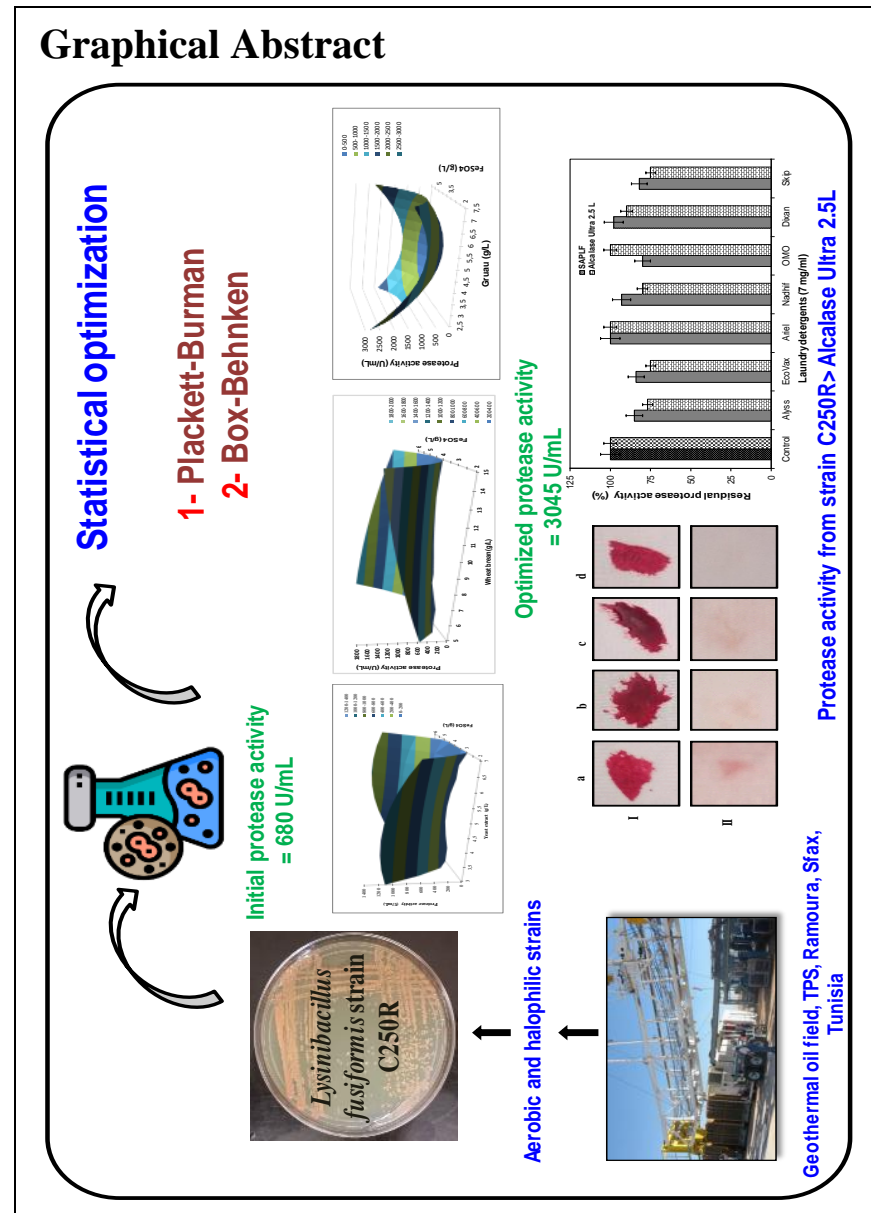

\begin{abstract}
.
In this study, we aimed to optimize the cultural and nutritional conditions for protease production by Lysinibacillus fusiformis strain C250R in submerged fermentation process using statistical methodology. The most significant factors (gruel, wheat bran, yeast extract, and $\mathrm{FeSO}_{4}$ ) were identified by Plackett-Burman design. Response surface methodology (RSM) was used to determine the optimum levels of the screened factors and their interaction. Under the optimized conditions, protease yield $3045 \mathrm{U} / \mathrm{mL}$ was 4.5 folds higher than those obtained by the use of the initial conditions $(680 \mathrm{U} / \mathrm{mL})$. Additionally, this research demonstrated that the protease activity of strain C250R has a high detergent compatibility and an excellent stain removal compared to Alcalase Ultra $2.5 \mathrm{~L}$; which offers an interesting potential for its application in the laundry detergent industry.
\end{abstract}

Keywords: Protease; Lysinibacillus fusiformis; Statistical methodology; Detergent formulations. 


\section{Introduction}

The biocatalysts are beautiful creatures and the best solution given by nature. They can be used to improve some biotechnological applications. Catalysis is a process that increases the speed with which a reaction reaches equilibrium. Since the reaction rate depends on the free energy of activation, a catalyst causes the decrease of the energy barrier and accelerates the catalytic stage. Enzymes are molecules which can reduce the activation energy of reaction and thus accelerate the biochemical reactions that take place in the cell (Bouhlel et al. 2021). Therefore, the functionality of a cell, its reproduction requires that all reactions occur in coordinated and controlled synergy. The enzymes are thus key players in life. Proteases, as multifunctional biocatalysts, account for about $60 \%$ of global markets enzymes, which have a wide range of applications. They are used in several industrial processes including detergents, baking, food, photography, and pharmaceuticals (Mechri et al. 2017).

Many bacterial species, such as Caldicoprobacter guelmensis strain D2C22 ${ }^{\mathrm{T}}$ (Bouacem et al. 2015), Gracilibacillus boraciitolerans strain LO15 (Ouelhadj et al. 2020), Melghiribacillus thermohalophilus Nari2 $\mathrm{A}^{\mathrm{T}}$ (Mechri et al. 2021), and Lysinibacillus fusiformis Strain SK (Khadka et al. 2020), are known to produce thermostable proteases.

The genus Lysinibacillus was found to be metabolically versatile with the ability to produce wide range of enzymes. Lysinibacillus fusiformis, a Gram-positive bacterium closely related to Bacillus sphaericus, was formerly known as Bacillus fusiformis before 2007 and later on reclassified as genus Lysinibacillus because of the presence of the specific amino acids like lysine, alanine, glutamic acid and aspartic acid in its cell wall. This bacterium can produce inactive spherical endospores resistant to high temperatures, detrimental chemicals and UV light under the active situations (Ahmed et al. 2007). Some study has revealed that Lysinibacillus fusiformis is capable of producing thermostable protease at a higher temperature (Khadka et al. 2020).

The main purpose of the present study is the statistical optimization of protease production from Lysinibacillus fusiformis strain C250R. The produced enzyme was characterized and evaluated for possible application in the laundry detergent industry.

\section{Material and methods}

\subsection{Screening for proteolytic microorganism isolate}

Lysinibacillus fusiformis strain C250R was isolated from the production water of the Ramoura oil field (onshore) at Tunisia, with a temperature of $95^{\circ} \mathrm{C}$, and salinity of $106 \mathrm{~g} / \mathrm{L}$ (Mnif et al. 2011). C250R strain was maintained on Luria-Bertani broth-agar (LB-agar) at $4{ }^{\circ} \mathrm{C}$ until further uses. The ability of the isolate for proteolytic activity was tested on skimmed milk agar plates (SMAP) as detailed beforehand by the authors (Ouelhadj et al. 2020) and then incubated at $37^{\circ} \mathrm{C}$ for $24 \mathrm{~h}$. A clear zone of hydrolysis indicating protease activity was measured in millimeters.

\subsection{Protease production}

A preliminary study for the production of protease production was carried out using a production medium containing per Liter 5 g gelatin, 1 g yeast extract, $50 \mathrm{~g} \mathrm{NaCl}, 2 \mathrm{~g} \mathrm{CaCl}_{2}, 1$ g MgSO $4.7 \mathrm{H}_{2} \mathrm{O}, 1 \mathrm{~g}$ $\mathrm{K}_{2} \mathrm{HPO}_{4}$, and $1 \mathrm{~g} \mathrm{KH}_{2} \mathrm{PO}_{4}$ at $\mathrm{pH}$ 7.4.

\subsection{Optimization of enzyme production}


The optimization of protease production from Lysinibacillus fusiformis strain C250R was started with the selection for the best carbon and nitrogen sources using the traditional method 'one variable at a time. The experiments were carried out in $250 \mathrm{~mL}$ Erlermeyer flasks containing $25 \mathrm{~mL}$ of production liquid medium.

The list of various used carbon sources was casein, gelatin, gruel, glucose, starch, and maltose. While, the list of used nitrogen sources was yeast extract, soya flour, meat extract, beef extract, (NH4)2SO4, and $\left.\left(\mathrm{NH}_{4}\right)_{3} \mathrm{FeSO}_{3}\right)$.

\subsubsection{Screening of factors with the Plackett-Burman design}

Seventeen variables (incubation temperature, initial $\mathrm{pH}$, speed of agitation, gruel, sucrose, lentil flour, wheat bran, yeast extract, urea, $\mathrm{NaNO}_{3}$, crude oil, $\mathrm{NaCl}, \mathrm{CaCl}_{2}, \mathrm{FeSO}_{4}, \mathrm{MnSO}_{4}$, trace elements, and $\mathrm{KH}_{2} \mathrm{PO}_{4}$ ) were studied at low (-1) and high (+1) levels of each factor (Table 1). The effect of each variable was carried out by the determination of the contrast coefficient (b) obtained from the difference between the measurements average made at the high (+) and the low (-) levels of the variable. 
Table 1 Levels of independent variables on the protease production of Lysinibacillus fusiformis strain C250R.

\begin{tabular}{|c|c|c|c|}
\hline \multirow[t]{2}{*}{ Code of variables } & \multirow[t]{2}{*}{ Variables } & \multicolumn{2}{|l|}{ Levels } \\
\hline & & Low $(-1)$ & $\operatorname{High}(+1)$ \\
\hline $\mathrm{X} 1$ & Temperature $\left({ }^{\circ} \mathrm{C}\right)$ & 30 & 37 \\
\hline $\mathrm{X} 2$ & $\mathrm{pH}$ & 7 & 9 \\
\hline $\mathrm{X} 3$ & Agitation (rpm) & 150 & 180 \\
\hline $\mathrm{X} 4$ & Gruel (g/L) & 5 & 10 \\
\hline $\mathrm{X} 5$ & Sucrose $(\mathrm{g} / \mathrm{L})$ & 0 & 5 \\
\hline $\mathrm{X} 6$ & Lentil flour (g/L) & 0 & 5 \\
\hline $\mathrm{X} 7$ & Wheat bran $(\mathrm{g} / \mathrm{L})$ & 0 & 5 \\
\hline X8 & Yeast extract $(\mathrm{g} / \mathrm{L})$ & 1 & 3 \\
\hline X9 & Urea $(g / L)$ & 0 & 2 \\
\hline X10 & $\mathrm{NaNO}_{3}(\mathrm{~g} / \mathrm{L})$ & 0 & 2 \\
\hline $\mathrm{X} 11$ & Crude oil $(\%, \mathrm{v} / \mathrm{v})$ & 1 & 4 \\
\hline $\mathrm{X} 12$ & $\mathrm{NaCl}(\mathrm{g} / \mathrm{L})$ & 20 & 50 \\
\hline $\mathrm{X} 13$ & $\mathrm{CaCl}_{2}(\mathrm{~g} / \mathrm{L})$ & 0 & 2 \\
\hline $\mathrm{X} 14$ & $\mathrm{FeSO}_{4}(\mathrm{~g} / \mathrm{L})$ & 1 & 3 \\
\hline $\mathrm{X} 15$ & $\mathrm{MnSO}_{4}(\mathrm{~g} / \mathrm{L})$ & 0 & 2 \\
\hline $\mathrm{X} 16$ & Trace elements $(\%, \mathrm{v} / \mathrm{v})$ & 1 & 3 \\
\hline $\mathrm{X} 17$ & $\mathrm{KH}_{2} \mathrm{PO}_{4}(\mathrm{~g} / \mathrm{L})$ & 1 & 2 \\
\hline
\end{tabular}

\subsubsection{Response surface methodology using box-Behnken design}

Based on the results of the Plackett-Burman design, four variables (gruel (X1), wheat bran (X2), yeast extract $(\mathbf{X 3})$, and $\mathrm{FeSO}_{4}(\mathbf{X} 4)$ ) were found to have a greater influence on protease production by the Lysinibacillus fusiformis strain C250R. Then, the Box-Behnken experimental design was performed to determine the level of the selected variables that influence protease production. These variables were prescribed into three levels, coded $-1,0$, and 1 . The realized modeling was based on the second order polynomial equation:

$$
y=b_{0}+\sum_{i=1}^{n} b_{i} x_{i}+\sum_{i=1}^{n} b_{i i} x_{i}^{2}+\sum_{i=j}^{n-1} \sum_{j=i+1}^{n} b_{i j} x_{i j}
$$

Where $y$ is the protease activity, $b_{0}$ is the offset term, $b_{i}$ is the linear effect, $b_{i i}$ is the squared effect, $b_{i j}$ is the first order interaction effect and $x_{i}$ is the independent variable.

\subsection{Assay of proteolytic activity}

The protease activity was assayed by a modified caseinolytic Peterson's method protocol using Hammerstein casein (Merck, Darmstadt, Germany) as a substrate (Peterson 1977). Enzyme solution (0.5 $\mathrm{mL}$ ) suitably diluted was mixed with $0.5 \mathrm{~mL} 100 \mathrm{mM}$ glycine- $\mathrm{NaOH}$ buffer supplemented with $2 \mathrm{mM}$ $\mathrm{CaCl}_{2}$ at $\mathrm{pH} 10$ (Buffer A) containing $10 \mathrm{~g} / \mathrm{L}$ of casein, and incubated for $15 \mathrm{~min}$ at $70^{\circ} \mathrm{C}$. The reaction 
was stopped by the addition of $0.5 \mathrm{~mL}$ TCA $20 \%$ (w/v). The mixture was allowed to stand at room temperature for $15 \mathrm{~min}$ and then centrifuged at $10,000 \mathrm{~g}$ for $15 \mathrm{~min}$ to remove the precipitate. The acid soluble material was estimated spectrophotometrically at $280 \mathrm{~nm}$. A standard curve was generated using solutions of $0-100 \mu \mathrm{g} / \mathrm{L}$ tyrosine. One unit (U) of protease activity was defined as the amount of enzyme, which liberated $1 \mathrm{mg}$ tyrosine per minute under the experimental conditions used. The proteolytic activity in presence of the laundry detergent solution was evaluated by the method suggested by Touioui Boulkour et al. (Touioui et al. 2015) using $N, N$-dimethylated casein (DMC) as a substrate. Unless otherwise stated, a suitably diluted enzyme solution $(0.5 \mathrm{~mL})$ was mixed with $1 \mathrm{~mL}$ laundry detergent, $2 \mathrm{~mL} 100 \mathrm{mM}$ borate-NaOH buffer (pH 9) containing $10 \mathrm{~g} / \mathrm{L} \mathrm{DMC}$, and $0.25 \mathrm{~mL}$ of $10 \mathrm{~g} / \mathrm{L} \mathrm{2,4,6-}$ trinitrobenzene sulfonic acid (TNBSA) as a color indicator. The mixture was shake-incubated at $70{ }^{\circ} \mathrm{C}$ for $25 \mathrm{~min}$, and the reaction was stopped by the addition of a $2.5 \mathrm{~mL}$ of cold water for $15 \mathrm{~min}$. The precipitate was then removed by centrifugation at 10,000 $\mathrm{g}$ for $15 \mathrm{~min}$. Absorbance was measured at 450 $\mathrm{nm}$. One unit of protease activity was defined as the amount of enzyme required to catalyze the liberation of $1 \mu$ mole of product from DMC per min under the experimental conditions used.

\subsection{Statistical analyses}

The data were analyzed using SPSS (Version 11.0.1 2001, LEAD Technologies, Inc., and USA). The response surface was plotted using Microsoft Excel software (Version 2007, Microsoft Inc., USA). All determinations were performed at least three independent replicates, and the control experiment without protease was carried out under the same conditions. The experimental results were expressed as the mean of the replicate determinations and standard deviation (mean $\pm \mathrm{SD}$ ). The statistical significance was evaluated using t-tests for two-sample comparison and one-way analysis of variance (ANOVA) followed by t-test. The results were considered statistically significant for $\mathrm{P}$ values of less than or equal to 0.05. The statistical analysis was performed using the R package Version 3.1.1 (Vanderbilt University, Nashville, TN, USA).

\section{Results and discussion}

\subsection{Screening of protease-producing strains}

The bacterial strain used for this study was isolated from the production water of the Ramoura oil field (onshore) at Tunisia (Mnif et al. 2011). It exhibited an interesting proteolytic activity by hydrolyzing casein with a zone of diameter on skimmed milk agar plates (SMAP) (Figure 1). The optimum production of protease is $680 \mathrm{U} / \mathrm{mL}$ achieved at $\mathrm{pH} 10$ and $70^{\circ} \mathrm{C}$ in an initial media composed per Litre from $5 \mathrm{~g}$ gelatin, $1 \mathrm{~g}$ yeast extract, $50 \mathrm{~g} \mathrm{NaCl}, 2 \mathrm{~g} \mathrm{CaCl}_{2}, 1 \mathrm{~g} \mathrm{MgSO} 4.7 \mathrm{H}_{2} \mathrm{O}, 1 \mathrm{~g} \mathrm{~K}_{2} \mathrm{HPO}_{4}$, and $1 \mathrm{~g} \mathrm{KH}_{2} \mathrm{PO}_{4}$ at $\mathrm{pH} 7.4$.

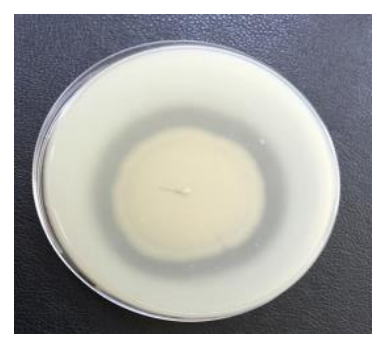

Fig. 1. Detection of protease activity on SMAP medium by Lysinibacillus fusiformis strain C250R. 


\subsection{Effect of carbon and nitrogen sources}

Protease production was tested in the initial medium containing $(\mathrm{g} / \mathrm{L})$ : yeast extract (as nitrogen source), $1 ; \mathrm{CaCl}_{2}, 2 ; \mathrm{KH}_{2} \mathrm{PO}_{4}, 1 ; \mathrm{FeSO}_{4}, 10$; trace elements $1 \%$; and $10 \mathrm{~g} / \mathrm{L}$ of different carbon and energy sources: casein, gelatin, gruel, starch, glucose and maltose. As shown in table 1, the best carbon source for protease production was gruel, $(680 \mathrm{U} / \mathrm{ml})$; followed by gelatin $(659 \mathrm{U} / \mathrm{ml})$. In general, both organic and inorganic nitrogen sources were used efficiently by Bacillus species, for protease production. In the present study, different organic (yeast extract, meat extract, beef extract, and soya flour) and inorganic [ammonium sulphate, $\left(\mathrm{NH}_{4}\right)_{2} \mathrm{SO}_{4}$ and ferric ammonium sulphate, $\mathrm{NH}_{4} \mathrm{Fe}\left(\mathrm{SO}_{4}\right)_{2}$ ] nitrogen sources, at a concentration of $2 \mathrm{~g} / \mathrm{L}$, were also tested in a medium containing gruel at $10 \mathrm{~g} / \mathrm{L}$ as a sole carbon and energy source. As shown in table 2, the best nitrogen source for protease production was yeast extract $(750 \mathrm{U} / \mathrm{ml})$ followed by meat extract $(400 \mathrm{U} / \mathrm{ml})$ and beef extract $(304 \mathrm{U} / \mathrm{ml})$. In the light of these results, the gruel and yeast extract turns out to be more adequate for the production of protease by Lysinibacillus fusiformis strain C250R. In fact, the gruel and yeast extract are two sources of amino acids and growth factors for the bacterium. They also contain vitamins and cofactors essential for the development of the bacterium and for the synthesis of metabolites as well.

Table 1: Effect of different carbon (5 g/L) (A) and nitrogen (2 g/L) (B) on proteases production by Lysinibacillus fusiformis strain C250R.

A

\begin{tabular}{llllllll}
\hline Carbon source & Control & Casein & Gelatin & Gruel & Glucose & Starch & Maltose \\
\hline Protease activity $(\mathrm{U} / \mathrm{mL})$ & 114 & 200 & 659 & $\mathbf{6 8 0}$ & 478 & 191 & 250 \\
Absorbance at $600 \mathrm{~nm}$ & 0.49 & 1.8 & 0.68 & $\mathbf{3}$ & 1.43 & 1.43 & 0.6 \\
\hline
\end{tabular}

B

\begin{tabular}{llllllll}
\hline Carbon source & Control & $(\mathrm{NH} 4)_{3} \mathrm{FeSO}_{3}$ & $(\mathrm{NH} 4)_{2} \mathrm{SO}_{4}$ & Soy flour & Yeast & Beef & Malt \\
\hline $\begin{array}{l}\text { Protease } \\
\text { activity }\end{array}$ & 91 & 241 & 300 & 182 & $\mathbf{6 8 0}$ & 304 & 400 \\
$\begin{array}{l}(\mathrm{U} / \mathrm{mL}) \\
\text { Absorbance at } 600 \mathrm{~nm}\end{array}$ & 2.23 & 2.8 & 6.15 & 5.77 & $\mathbf{3 . 5}$ & 3.17 & 4.12 \\
\hline
\end{tabular}

\subsection{Screening of significant variables using Plackett-Burman design}

The Plackett-Burman design is widely used in biotechnological production because it allows the screening of main factors from a large number of variables that can be retained in the further optimization process (Sathish Kumar et al. 2014). In this study, we first used the Plackett-Burman design to screen the most influential variables on Lysinibacillus fusiformis strain C250R protease production. Seventeen different variables including some operational parameters and medium components were screened using a 19 runs matrix. Levels of the factors tested for the production of proteases by strain C250R using Plackett-Burman methodology are presented in Table 1. The data showed a wide variation of protease activity production ranging from 680 to $3045 \mathrm{U} / \mathrm{ml}$. This variation proved the importance of this step in selecting the most influent factors and the level of the others.

The main effect of each variable was estimated by evaluating the contrast coefficient $(b)$. Result analysis showed that gruel, wheat bran, yeast extract and $\mathrm{FeSO}_{4}$ were the most significant variables that 
present the largest contrast coefficient. In fact, wheat bran, yeast extract and $\mathrm{FeSO}_{4}$ concentration had a positive effect on protease production, while the gruel concentration exhibited a negative effect. The design matrix with the corresponding results of Plackett-Burman experiments is presented in Table 3. For further optimization, the level of the most significant factors was optimized by RSM using BoxBehnken design while insignificant ones were used in all trials at their optimum level. The other variables with positive effect (speed of agitation, crude oil, $\mathrm{MnSO}_{4}$, trace elements and $\mathrm{KH}_{2} \mathrm{PO}_{4}$ ) were fixed at high level while variables with a negative effect (temperature, initial $\mathrm{pH}$, sucrose, lentil flour, urea, $\mathrm{NaNO}_{3}, \mathrm{NaCl}$, and $\mathrm{CaCl}_{2}$ ) were maintained at low level.

Table 3 Experimental design using the Plackett-Burman method for screening of factors affecting protease production.

\begin{tabular}{|c|c|c|c|c|c|c|c|c|c|c|c|c|c|c|c|c|c|c|c|}
\hline Run & Global & $\mathrm{X}_{1}$ & $\mathrm{X}_{2}$ & $\mathrm{X}_{3}$ & $\mathrm{X}_{4}$ & $\mathrm{X}_{5}$ & $\mathrm{X}_{6}$ & $\mathrm{X}_{7}$ & $\mathrm{X}_{8}$ & $\mathrm{X}_{9}$ & $\mathrm{X}_{10}$ & $\mathrm{X}_{11}$ & $\mathrm{X}_{12}$ & $\mathrm{X}_{13}$ & $\mathrm{X}_{14}$ & $\mathrm{X}_{15}$ & $\mathrm{X}_{16}$ & $\mathrm{X}_{17}$ & $\begin{array}{l}\text { Protease } \\
\text { activity } \\
(\mathrm{U} / \mathrm{ml})^{\mathrm{a}}\end{array}$ \\
\hline 1 & + & + & + & + & + & + & + & + & + & + & + & + & + & + & + & + & + & + & 0 \\
\hline 2 & + & - & + & - & - & + & + & + & + & - & + & - & + & - & - & - & - & + & 1137 \\
\hline 3 & + & - & - & + & - & - & + & + & + & + & - & + & - & + & - & - & - & - & 1682 \\
\hline 4 & + & + & - & - & + & - & - & + & + & + & + & - & + & - & + & - & - & - & 1182 \\
\hline 5 & + & + & + & - & - & + & - & - & + & + & + & + & - & + & - & + & - & - & 0 \\
\hline 6 & + & - & + & + & - & - & + & - & - & + & + & + & + & - & + & - & + & - & 1182 \\
\hline 7 & + & - & - & + & + & - & - & + & - & - & + & + & + & + & - & + & - & + & 728 \\
\hline 8 & + & - & - & - & + & + & - & - & + & - & - & + & + & + & + & - & + & - & 0 \\
\hline 9 & + & + & - & - & - & - & + & + & - & - & + & - & - & + & + & + & + & - & 910 \\
\hline 10 & + & - & + & - & - & - & - & + & + & - & - & + & - & - & + & + & + & + & 3045 \\
\hline 11 & + & + & - & + & - & - & - & - & + & + & - & - & + & - & - & + & + & + & 1500 \\
\hline 12 & + & - & + & - & + & - & - & - & - & + & + & - & - & + & - & - & + & + & 0 \\
\hline 13 & + & + & - & + & - & + & - & - & - & - & + & + & - & - & + & - & - & + & 364 \\
\hline 14 & + & + & + & - & + & - & + & - & - & - & - & + & + & - & - & + & - & - & 0 \\
\hline 15 & + & + & + & + & - & + & - & + & - & - & - & - & + & + & - & - & + & - & 0 \\
\hline 16 & + & + & + & + & + & - & + & - & + & - & - & - & - & + & + & - & - & + & 546 \\
\hline 17 & + & - & + & + & + & + & - & + & - & + & - & - & - & - & + & + & - & - & 637 \\
\hline 18 & + & - & - & + & + & + & + & - & + & - & + & - & - & - & - & + & + & - & 0 \\
\hline 19 & + & + & - & - & + & + & + & + & - & + & - & + & - & - & - & - & + & + & 319 \\
\hline$\varpi$ & $\begin{array}{l}a \\
\text { a } \\
\text { N }\end{array}$ & $\begin{array}{l}\stackrel{1}{\infty} \\
\infty \\
\dot{0}\end{array}$ & $\frac{1}{\dot{N}}$ & $\begin{array}{l}\stackrel{N}{N} \\
\stackrel{N}{=}\end{array}$ & $\begin{array}{l}\omega_{w}^{\prime} \\
\dot{w}\end{array}$ & $\underset{\infty}{+\infty}$ & $\begin{array}{l}\infty \\
\infty \\
\infty \\
N\end{array}$ & $\begin{array}{l}\omega \\
\infty \\
\omega\end{array}$ & $\begin{array}{l}\text { Na } \\
\dot{\omega}\end{array}$ & $\frac{\dot{N}}{N}$ & $\begin{array}{l}\dot{1} \\
\dot{N}\end{array}$ & $\stackrel{\sim}{+}$ & $\begin{array}{l}\dot{w} \\
\dot{w}\end{array}$ & $\begin{array}{l}\text { N } \\
\infty \\
i \\
\text { ur }\end{array}$ & $\stackrel{\omega}{\omega}_{\infty}^{\omega}$ & $\frac{N}{A}$ & $\begin{array}{l}\omega \\
\dot{\sim} \\
0\end{array}$ & $\begin{array}{l}\overrightarrow{0} \\
\dot{\infty}\end{array}$ & \\
\hline
\end{tabular}

${ }^{\text {a }}$ Values represent means of three replicates.

B: Contrast coefficient.

\subsection{Level optimization of the main factors using response surface methodology (RSM)}

Based on the results given above, four factors namely gruel, wheat bran, yeast extract and $\mathrm{FeSO}_{4}$ were chosen as critical variables affecting protease production. The design matrix with the corresponding results of Box-Behnken experiments, as well as the predicted results is presented in Table 4. 
The model was established after the regression analysis and was predicted by the following equation:

$\mathrm{Y}=8991.906-2239.733 \times X_{1}+147.683 \times \mathrm{X}_{2}+348.229 \times \mathrm{X}_{3}-2419.875 \times \mathrm{X}_{4}+173.160 \times \mathrm{X}_{1} \times \mathrm{X}_{1}+$ $12.739 \times \mathrm{X}_{1} \times \mathrm{X}_{2}+77.699 \times \mathrm{X}_{1} \times \mathrm{X}_{4}-4.264 \times \mathrm{X}_{2} \times \mathrm{X}_{2}+12,5 \times \mathrm{X}_{2} \times \mathrm{X}_{3}-40.900 \times \mathrm{X}_{2} \times \mathrm{X}_{4}-63.468$ $\times \mathrm{X}_{3} \times \mathrm{X}_{3}+39.874 \times \mathrm{X}_{3} \times \mathrm{X}_{4}+273.437 \times \mathrm{X}_{4} \times \mathrm{X}_{4}$

When $\mathbf{Y}$ is the protease activity $(\mathrm{U} / \mathrm{ml}), \mathbf{X}_{1}, \mathbf{X}_{2}, \mathbf{X}_{\mathbf{3}}$ and $\mathbf{X}_{\mathbf{4}}$ are respectively gruel $(\mathrm{g} / \mathrm{L})$, wheat bran, $(\mathrm{g} / \mathrm{L})$, yeast extract $(\mathrm{g} / \mathrm{L})$ and $\mathrm{FeSO}_{4}(\mathrm{~g} / \mathrm{L})$. The regression analysis result showed that the $F$-value was 3.417 with a very low probability value $(P<0.001)$ indicating the significance of the model. The closeness of experimental and predicted protease activity can be expressed by the determination coefficient of $\left(\mathrm{R}^{2}=0.88\right)$ which stipulates that only $12 \%$ of the total variation could not be explained by the model. Adjusted $\mathrm{R}$ Square (predicted $\mathrm{R}_{2}$ ) of 0.774 explains the good agreement between the experimental and the predicted results. The model equation related to protease production shows an important negative linear effect for gruel $\left(\mathbf{X}_{1}\right)$ and $\mathrm{FeSO}_{4}\left(\mathbf{X}_{4}\right)$ and significant interactions between gruel and $\mathrm{FeSO}_{4}\left(\mathbf{X}_{1} \mathbf{X}_{4}\right)$, wheat bran and $\mathrm{FeSO}_{4}\left(\mathbf{X}_{2} \mathbf{X}_{4}\right)$ and yeast extract and $\mathrm{FeSO}_{4}\left(\mathbf{X}_{3} \mathbf{X}_{4}\right)$. These results were confirmed by the Student's $t$-test $(\alpha=0.05)$.

Response surface plot was generally the graphical representation of the regression equation, from which the response (protease production) is plotted against any two variables, while other variables were fixed at their middle levels. Response surface plots can directly reflect the impact of various factors on the response. Contour map traits can reflect the strength of the interaction between the two factors: an oval contour indicates that the interaction between the two factors is strong, whereas a circular contour indicates that the interaction between the two factors is weak (Wang et al. 2015). Fig. 2 shows the mutual interaction between the gruel and $\mathrm{FeSO}_{4}\left(\mathbf{X}_{\mathbf{1}} \mathbf{X}_{4}\right)$ and yeast. An increase in protease production was recorded in the minimum levels of the two factors. Thus, the protease activity variation was observed with the simultaneous decrease or increase of these two factors.

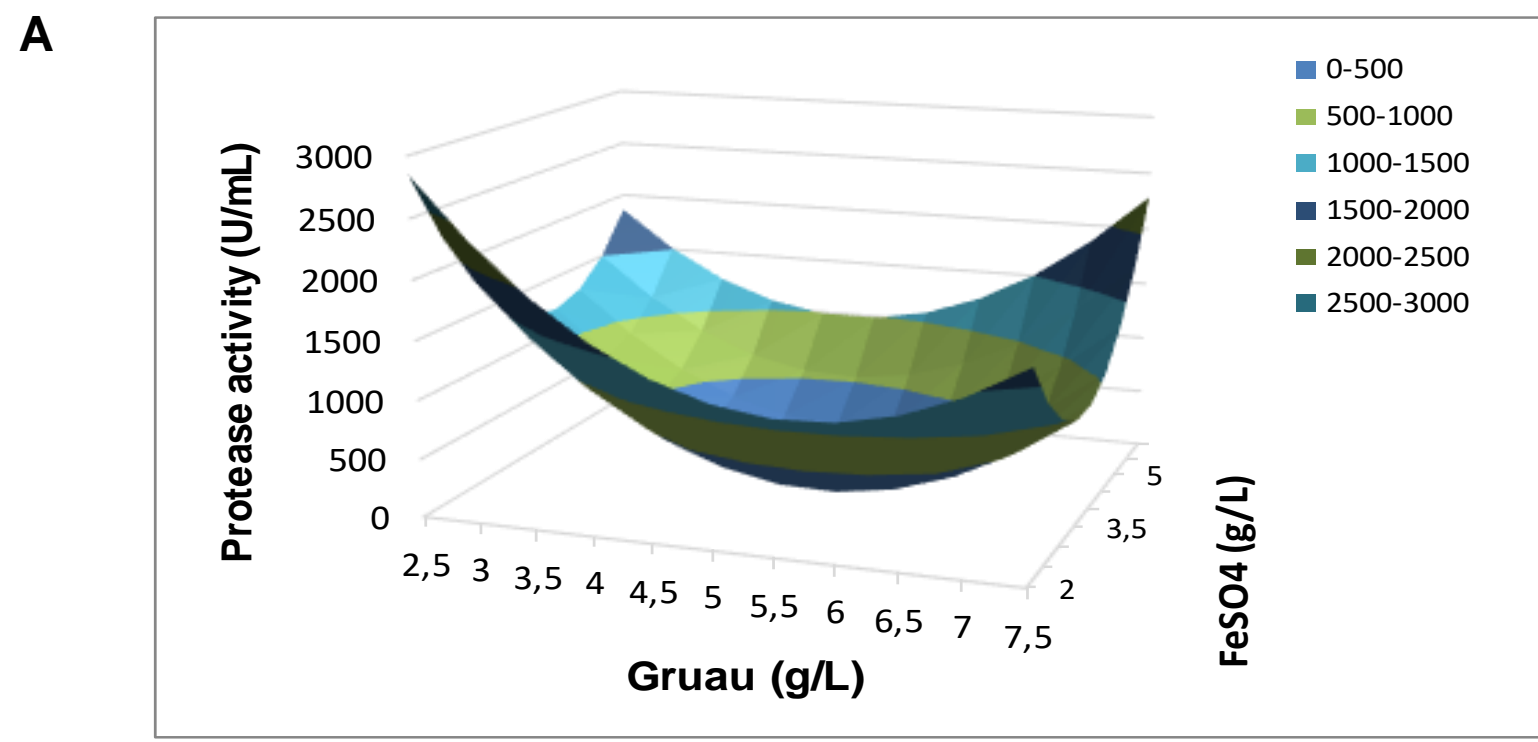


B

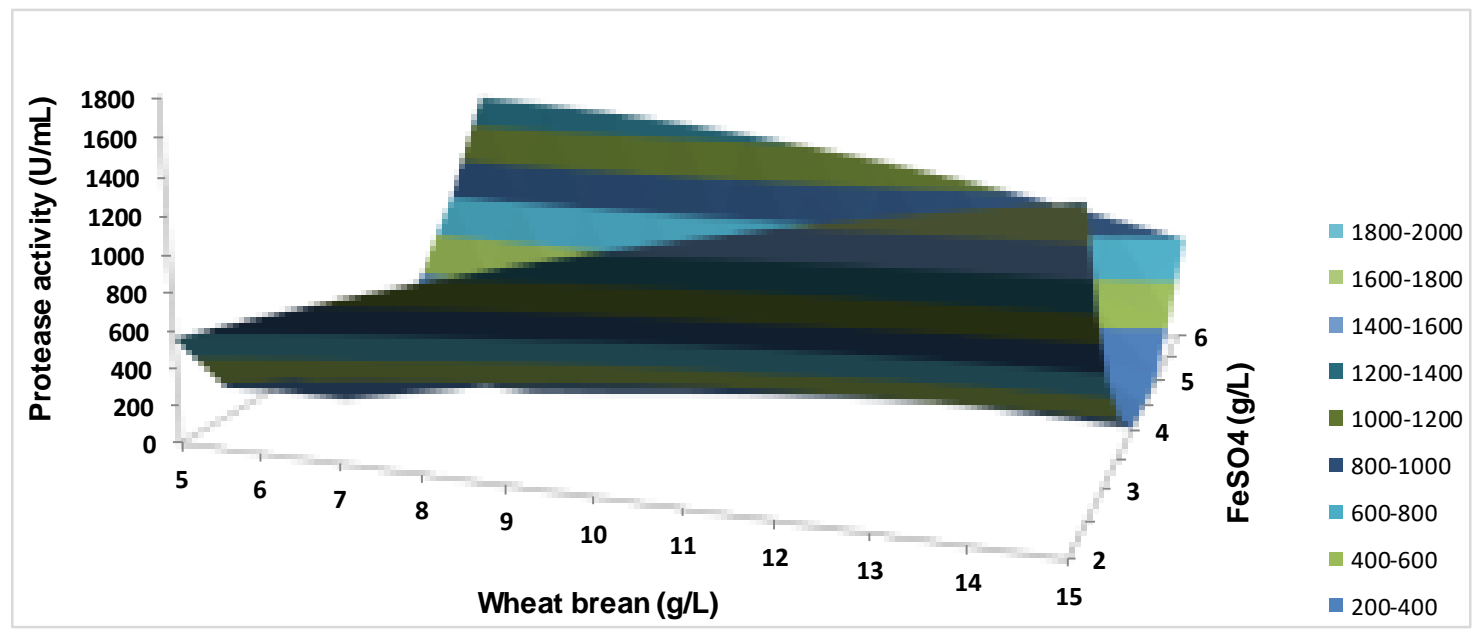

C

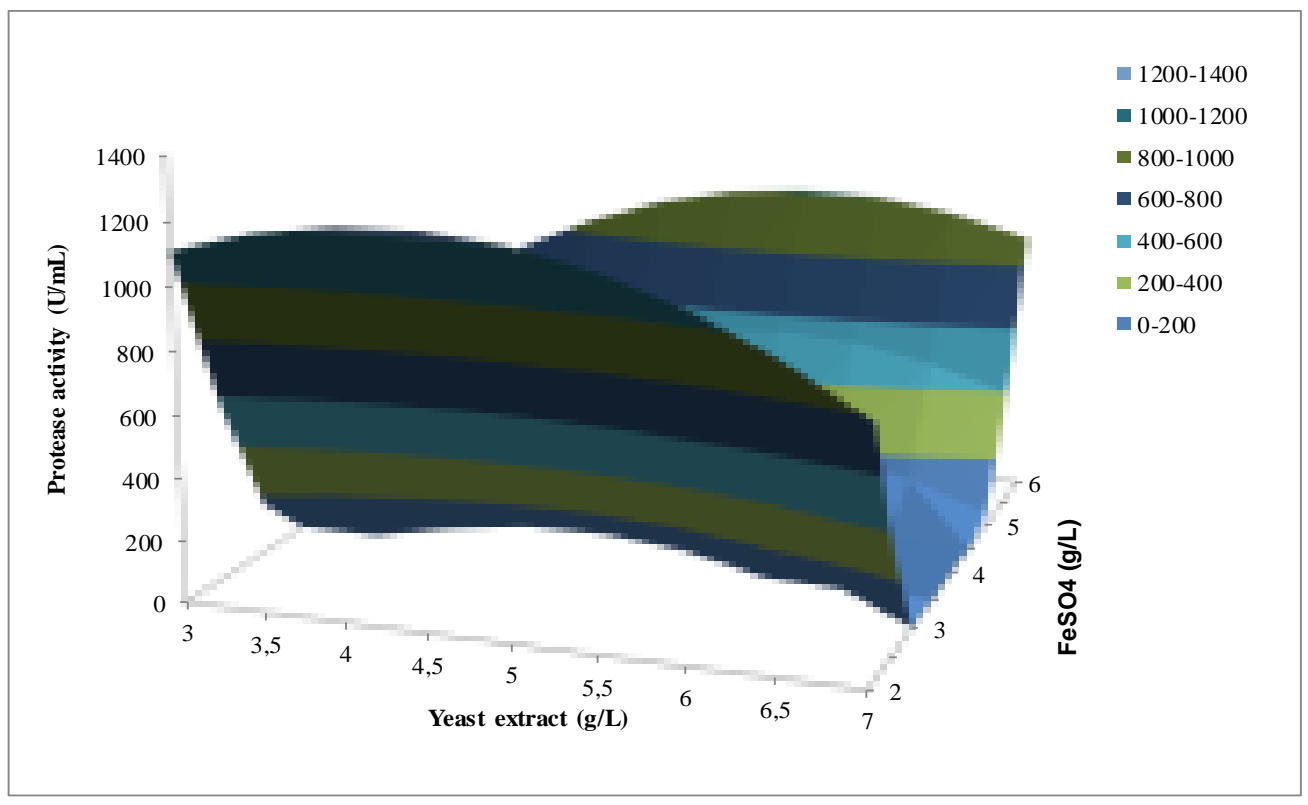

Fig. 2. Response surface plot of proteolytic enzyme production showing the interactive effects of the $\mathrm{FeSO}_{4}$ and gruel concentrations (A), $\mathrm{FeSO}_{4}$ and wheat bran concentrations (B) and $\mathrm{FeSO}_{4}$ and yeast extract concentrations $(\mathrm{C})$.

\subsection{Model validation}

The model validity was examined by additional experiments using the optimal culture conditions: temperature $30{ }^{\circ} \mathrm{C}$, initial $\mathrm{pH} 7$, speed of agitation $180 \mathrm{rpm}$, gruel $(5 \mathrm{~g} / \mathrm{L})$, wheat bran $(15 \mathrm{~g} / \mathrm{L})$, yeast extract (5 g/L), crude oil (4\%, v/v), $\mathrm{NaCl}(20 \mathrm{~g} / \mathrm{L}), \mathrm{FeSO}_{4}(2 \mathrm{~g} / \mathrm{L}), \mathrm{MnSO}_{4}(2 \mathrm{~g} / \mathrm{L})$, trace elements (3\%, $\mathrm{v} / \mathrm{v})$, and $\mathrm{KH}_{2} \mathrm{PO}_{4}(2 \mathrm{~g} / \mathrm{L})$. Protease production yield $(3100 \mathrm{U} / \mathrm{ml})$ was absolutely more important than that obtained during the preliminary study $(680 \mathrm{U} / \mathrm{ml})$. Thus, protease activity was multiplied by a factor of 4.55 fold. The expected result $(3114.75 \mathrm{U} / \mathrm{ml})$ was very close to the experimental result $(3100 \mathrm{U} / \mathrm{ml})$. By optimizing the medium composition and the culture conditions, not only the production of proteases 
was enhanced but also the cost of enzyme production was reduced, since two cheap and readily available complex substrates (gruel and wheat bran) were used.

\subsection{Performance evaluation of protease activity from strain C250R}

\subsubsection{Stability and compatibility with laundry detergents}

The use of proteases as detergent additives represents a major application of industrial enzymes. To be suitable, they must be active under thermophilic $\left(60^{\circ} \mathrm{C}\right)$ and alkalophilic $(\mathrm{pH} 9-11)$ conditions, as well as in the presence of the various laundry detergents (Adrio and Demain 2014). According to Fig. $5 \mathrm{C}$, this protease was extremely stable and compatible with the commercial solid detergents used, retaining $84 \%$ of its initial activity with Ecovax and $85 \%$ with Alyss even after $1 \mathrm{~h}$ incubation at $40{ }^{\circ} \mathrm{C}$. However, Alcalase Ultra $2.5 \mathrm{~L}$ was noted to be less stable in the presence of Eovax and Alyss, retaining respectively only $75 \%$ and $77 \%$ of its initial activity. In addition, the protease from Lysinibacillus fusiformis strain C250R was highly stable in the presence of liquid laundry detergents at a concentration of $7 \mathrm{mg} / \mathrm{mL}$ (Fig. 3). The alkaline protease exhibited higher stability in Ariel, Dixan, than in Nadhif and Skip. However, Alcalase Ultra 2.5 L was noted to be less stable in the presence of Nadhif, retaining only $80 \%$ of its initial activity. Detergent stable proteases with variable stability in the presence of different detergents have been studied by several other researchers (Singh et al. 2012, Deng et al. 2010). Mechri et al. (Mechri et al. 2017) reported an alkaline protease from Aeribacillus pallidus strain VP3 with 60$100 \%$ residual activity when incubated with $7 \mathrm{mg} / \mathrm{ml}$ commercial detergents for $1 \mathrm{~h}$ at $45{ }^{\circ} \mathrm{C}$. These results support the potential of protease from only $75 \%$ and $77 \%$ of its initial activity. In addition, the protease from Lysinibacillus fusiformis strain C250R as an ideal candidate for use in laundry detergent.

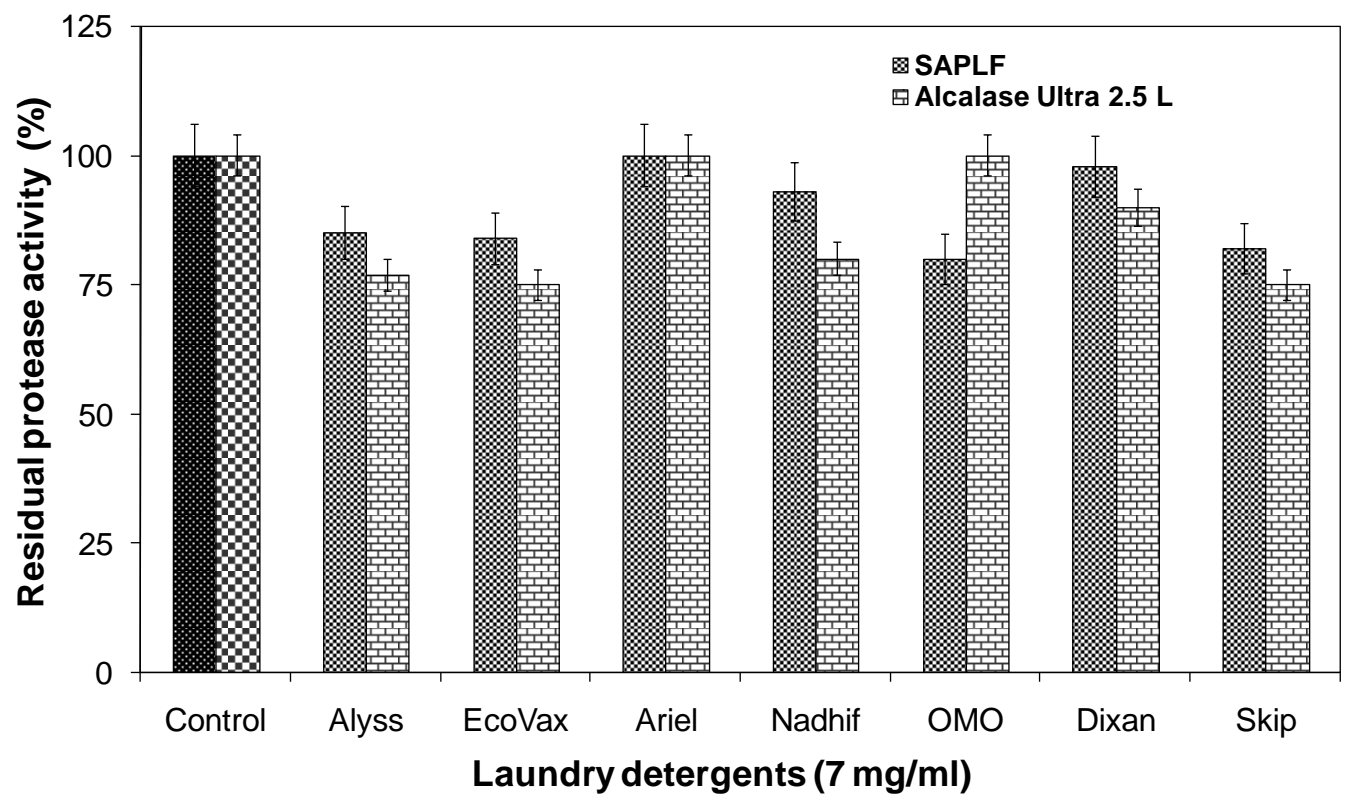

Fig. 3. Stability of the protease from strain C250R and Alcalase Ultra $2.5 \mathrm{~L}$ in the presence of liquid and solid laundry detergents. Enzyme activity of the control sample, which contained no additive and incubated under similar conditions, was taken as $100 \%$. Each point represents the mean of three independent experiments. 


\subsubsection{Removal of blood stains from cotton fabrics}

With the progress of urbanization, there is growing interest in detergent industries, especially to prepare bio-formulations effective for removal of various types of stains on the fabric (Hemlata et al. 2016). Removal of proteinaceous stains such as that of blood, grass, and sauces always remained a challenge to laundry workers in addition to households. The role of protease as an additive in detergent formulations has long been maintained. In laundry detergents, they account for approximately $25 \%$ of the total worldwide sales of enzymes (Adrio and Demain 2014). The success of subtilisins in the field of industrial detergents is based on their stability and high substrate specificity. The application of protease from Lysinibacillus fusiformis strain C250R in detergents was represented in the Fig. 4. The stained cloth was washed with prepared detergent solutions without and with the protease from Lysinibacillus fusiformis strain C250R.

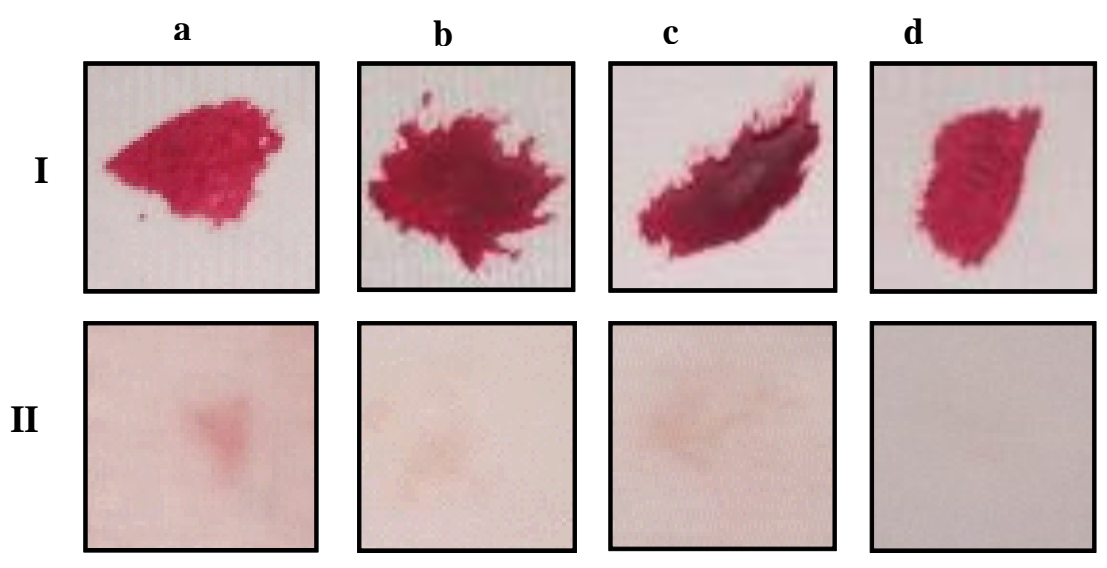

Fig. 4. Washing performance analysis test of our protease in the presence of the commercial detergent Ariel. (a) Cloth stained with blood washed with tap water; (b) blood-stained cloth washed with Ariel detergent (7 mg/ml), (c) bloodstained cloth washed with Ariel added with Alcalase Ultra $2.5 \mathrm{~L}$ (commercial enzyme, $500 \mathrm{U} / \mathrm{ml}$ ), (d)

blood-stained cloth washed with Ariel added with C250R protease (500 U/ml). I: untreated cloths (control) and II: treated cloths.

We noticed a limited washing performance with detergent (Ariel) only. The supplementation of our enzyme or commercial protease Alcalase Ultra $2.5 \mathrm{~L}$ in detergent seems to improve the cleansing process as evidenced by rapid blood stain removal when compared to detergent alone. In fact, our protease facilitated the release of proteinacious materials in a much easier way than the currently used Alcalase Ultra $2.5 \mathrm{~L}$ protease. Furthermore, the combination of protease from strain C250R with the Ariel detergent resulted in the complete stain removal (Fig. 4). These results confirm the newly isolated alkaline protease SAPLF from strain C250R as an effective cleaner of stains.

Alkaline proteases have been used in the detergents to hydrolyze and clean proteinaceous stains on garments (Choudhary 2012). Jaouadi et al. (Jaouadi et al. 2009) reported the stain removal using protease in cotton fabric to remove blood stains completely. The alkaline SAPB protease produced by Bacillus pumilus strain CBS was capable of cleaning stains but its mixture with detergent was proved to be more effective. Additionally, the protease isolated from mutant Bacillus licheniformis used in stained cloth increased ability to remove blood stain from cotton cloth (Kumari and Rani 2013). 


\section{Conclusions}

In this research, Plackett-Burman and Box-Behnken designs were employed to optimize the medium and culture conditions for the production of detergent stable protease by strain C250R. Compared to other proteases and the commercial Alcalase Ultra 2.5 L enzyme, the protease from this strain showed high stability and compatibility with a wide range of commercialized laundry detergents, making it particularly suitable for detergent formulations. Accordingly, further studies, some of which are currently underway in our laboratories, are needed to clone the encoding gene and to explore the structure-function relationships of the enzyme.

\section{Acknowledgments}

The authors are grateful to Mrs. N. Masmoudi and Mr. K. Walha (Analysis Unit-CBS) for their technical assistance.

\section{Funding information}

This work was supported by the Ministère de l'Enseignement Supérieur et de la Recherche Scientifique (MESRS) in Tunisia in the framework of the Contract Programs LBMIE-CBS, code grant no.: LR15CBS06 (2015-2018) and LBMEB-CBS, code grant no.: LR19CBS05 (2019-2022), the Multilateral Project Partenariats Hubert Curien (PHC)-Maghreb 2020 Program (FranMaghZYM 20202023, code Campus France: 43791TM \& code PHC: 01MAG20), and the Algerian-Tunisian R\&I Cooperation for the Mixed Laboratories of Scientific Excellence 2021-2024, code LABEX/TN/DZ/21/01.

\section{References}

Bouhlel, M., Brini, F. and Saibi, W. (2021) Exploring the milk-clotting activity and leather industry of Agave americana serine protease (PAA). Biochem. Mol. Biol. 7, 15.

Mechri, S., Ben Elhoul Berrouina, M., Omrane Benmrad, M., Zaraî Jaouadi, N., Rekik, H., Moujehed, E., Chebbi, A., Sayadi, S., Chamkha, M., Bejar, S. and Jaouadi, B. (2017) Characterization of a novel protease from Aeribacillus pallidus strain VP3 with potential biotechnological interest. Int. J. Biol. Macromol. 94, 221-232.

Bouacem, K., Bouanane-Darenfed, A., Laribi-Habchi, H., Ben Elhoul, M., Hmida-Sayari, A., Hacene, H., Ollivier, B., Fardeau, M. L., Jaouadi, B. and Bejar, S. (2015) Biochemical characterization of a detergent-stable serine alkaline protease from Caldicoprobacter guelmensis. Int. J. Biol. Macromol. 81, 299-307.

Ouelhadj, A., Bouacem, K., Asmani, K. L., Allala, F., Mechri, S., Yahiaoui, M. and Jaouadi, B. (2020a) Identification and homology modeling of a new biotechnologically compatible serine alkaline protease from moderately halotolerant Gracilibacillus boraciitolerans strain LO15. Int. J. Biol. Macromol. 161, 1456-1469.

Mechri, S., Jaouadi, N.Z., Bouacem, K., Allala, F., Bouraoui, A., Ferard, C., Rekik, H., Noiriel, A., Abousalham, A. and Bouanane-Darenfed, A. (2021) Cloning and heterologous expression of 
subtilisin SAPN, a serine alkaline protease from Melghiribacillus thermohalophilus Nari2 $\mathrm{A}^{\mathrm{T}}$ in Escherichia coli and Pichia pastoris. Process Biochem. 105, 27-41.

Khadka, S., Adhikari, S., Thapa, A., Panday, R., Adhikari, M., Sapkota, S., Regmi, R.S., Adhikari, N.P., Proshad, R. and Koirala, N. (2020) Screening and optimization of newly isolated thermotolerant Lysinibacillus fusiformis strain SK for protease and antifungal activity. Current Microbiol. 77, 1558-1568.

Ahmed, I., Yokota, A., Yamazoe, A. and Fujiwara, T. (2007) Proposal of Lysinibacillus boronitolerans gen. nov. sp. nov., and transfer of Bacillus fusiformis to Lysinibacillus fusiformis comb. nov. and Bacillus sphaericus to Lysinibacillus sphaericus comb. nov. Int. J. Syst. Evol. Microbiol. 57, 1117-1125.

Mnif, S., Chamkha, M., Labat, M. and Sayadi, S. (2011) Simultaneous hydrocarbon biodegradation and biosurfactant production by oilfield-selected bacteria. Journal of Applied Microbiology 111, 525536.

Peterson, G.L. (1977) A simplification of the protein assay method of Lowry et al. which is more generally applicable. Anal. Biochem. 83, 346-356.

Touioui, Boulkour S., Jaouadi, Zarai N., Boudjella, H., Ferradji, F.Z., Belhoul, M., Rekik, H., Badis, A., Bejar, S. and Jaouadi, B. (2015) Purification and biochemical characterization of two detergentstable serine alkaline proteases from Streptomyces sp. strain AH4. World J. Microbiol. Biotechnol. 31, 1079-1092.

Sathish Kumar, R., Ananthan, G. and Selva Prabhu, A. (2014) Optimization of medium composition for alkaline protease production by Marinobacter sp. GA CAS 9 using response surface methodology - A statistical approach. Biocatal. Agric. Biotechnol. 3, 191-197.

Wang, L., Zhang, B., Han, J., Zheng, Y., Li, J. and Shan, A. (2015) Optimization of hydrolysis condition of blood meal by Bacillus subtilis with response surface methodology. Int. Biodeter. Biodegr. 104, 112-117.

Adrio, J.L. and Demain, A.L. (2014) Microbial enzymes: tools for biotechnological processes. Biomolecules 4, 117-139.

Singh, S.K., Singh, S.K., Tripathi, V.R. and Garg, S.K. (2012) Purification, characterization and secondary structure elucidation of a detergent stable, halotolerant, thermoalkaline protease from Bacillus cereus SIU1. Process Biochem. 47, 1479-1487.

Deng, A., Wu, J., Zhang, Y., Zhang, G. and Wen, T. (2010) Purification and characterization of a surfactant-stable high-alkaline protease from Bacillus sp. B001. Bioresour. Technol. 101, 71007106.

Hemlata, B., Uzma, Z. and Tukaram, K. (2016) Substrate kinetics of thiol activated hyperthermostable alkaline lipase of Bacillus sonorensis $4 \mathrm{R}$ and its application in bio-detergent formulation. Biocatal. Agric. Biotechnol. 8, 104-111.

Choudhary, V. (2012) Compatibility with commercial detergents and stain removal capability of Aspergillus versicolor protease. J. Acad. Indus. Res. 16, 301-305

Jaouadi, B., Ellouz-Chaabouni, S., Ali, M.B., Messaoud, E.B., Naili, B., Dhouib, A. and Bejar, S. (2009) Excellent laundry detergent compatibility and high dehairing ability of the Bacillus pumilus CBS alkaline proteinase (SAPB). Biotechnol. Bioprocess Eng. 14, 503-512.

Kumari, B.L. and Rani, M.R. (2013) Characterization studies on caseinolytic extracellular alkaline protease from a mutant Bacillus licheniformis. Int. J. Life Sc. Bt. Pharm. Res.1, 284-289. 